\title{
Servitude and Work at the Dawn of the Early Modern Era The Devaluation of Salaried Workers and the "Undeserving Poor"
}

\author{
Giacomo Todeschini
}

For a historian accustomed to thinking about the social, cultural, and symbolic meaning of wealth and labor during the premodern era, the guiding thread of Thomas Piketty's book on capital in the twenty-first century appears to be an indepth reflection on the false meritocracy characteristic of the modern economic system. The wealthiest individuals, who between them appropriate most of the profits produced by twenty-first-century capitalist societies, present themselves, and are presented to the world, as highly deserving. Their often spectacular wealth is perceived and represented on the political and economic stages and in the media as the quantifiable facet of their dignity - an exceptional merit arising from the exceptional value of their work, skills, and dynamism. Within this framework the great majority of workers, more or less poor, appear as a mass devalorized by its inability to produce or to understand the meaning of capitalized wealth. Poverty, social minority, and civic inequality emerge as three complementary forms of indignity, even a shameful inability. ${ }^{1}$ It is reasonable to wonder whether this equation of poverty with unworthiness has a history, and upon closer inspection it becomes clear that the link between wealth and merit stretches back a long way. In fact, 
this representation of powerless workers as figures of incompetence, and thus justly poor, has its roots in the Middle Ages and the early modern period, where it was anchored in a system of thought and a social and economic practice that presented themselves as shaping the "common good" and the abolition of servitude.

Historians often consider Étienne de La Boétie's Discourse on Voluntary Servitude of 1574 as an early manifestation of freethinking that incited the people to liberate themselves from the bonds of servitude, revealed the logic governing the dialectic between dominant and dominated groups, and denounced subservience as contrary to the natural freedom of men. However, a careful reading of passages from the Discourse touching on "lower-class, common folk" or the "nature of common people" reveals a conceptual core that resembles the reflections of medieval Scholastics on the connection between servitude and the subordinate nature of certain peoples and individuals.

The nature of man is to be free and to wish to be so; but his nature is also such that he follows naturally the bent given him by his nurture. ... You should not imagine that any bird is more easily taken in by a decoy, or any fish swallows the hook more rapidly for an appetizing worm, than all people are quickly tempted into servitude by the slightest lure that is passed before their mouths, as they say; it is amazing how quickly they let themselves go if only you titillate them. ${ }^{2}$

This distinction between "man" and "people" is typical of a cultural tradition, Scholastic as much as "humanist," that was keen to test the existence of a genuine human dignity in everyday experience, one that would manifest itself in people's actual lives. It invites scholars to reflect on the connections between Piketty's analysis of the false meritocracy used to justify modern excesses of economic and social inequality, and the old European economic discourse about the natural social inferiority and economic incompetence of salaried workers.

Piketty's argument insists on the return of a logic of "inequality" 3 in the twenty-first century, an inequality that greatly resembles the disproportional wealth gaps of the early nineteenth century and is almost identical to the situation at the beginning of the twentieth, with a restricted minority of rentiers/capitalists opposed to an enormous majority of poor people, even salaried workers. Building on this

2. Étienne de La Boétie, Discourse on Voluntary Servitude, trans. James B. Atkinson and David Sices (Indianapolis: Hackett, 2012), 17 and 23. Among the recent works illustrating the historiographical impact of the Discourse as an example of libertarian protohumanism, see: Roland Bleiker, Popular Dissent, Human Agency and Global Politics (Cambridge: Cambridge University Press, 2000); and "La pensée libertaire. De La Boétie à Guy Debord, en passant par Proudhon," special issue, Les dossiers du Magazine littéraire ([2004] 2013). For a critical analysis of the text, see Jean Terrel, "Républicanisme et droit naturel dans le Discours de la servitude volontaire : une rencontre aporétique," Erytheis 4 (2009): http://idt.uab.es/erytheis/numero4/terrel.html.

3. Thomas Piketty, Capital in the Twenty-First Century, trans. Arthur Goldhammer (Cambridge/London: Harvard University Press, 2014), with the online technical appendix available at http://piketty.pse.ens.fr/en/capital21c2. 
observation, Piketty's argument can suggest a dual reflection to historians of premodern economic thought and language. From the outset, it is remarkable that the amount of wealth accumulated by Europe's top centile at the beginning of the twenty-first century (approximately 25 percent of the total wealth) corresponds not only to the situation of absolute economic domination characterizing early twentiethcentury rentiers, but also to the situation of economic and social inequality typical of fifteenth-century Florence, where 1 percent of citizens owned approximately a quarter of the existing capital. ${ }^{4}$ The ability to compare contemporary economic data with data from the late Middle Ages raises the question-fundamental for economic history as well as for the history of premodern economic thought-of a historically recurring relation between the social role of salaried workers, their place in discourses on Western economic organization, and their level of subsistence. This in turn prompts an analysis of the relations between servitude and work during the preindustrial period. ${ }^{5}$ This is both a political and an economic issue, but it is also a major issue for the history of a system of economic thought that, like classical economic thought, developed over the eighteenth and nineteenth centuries while retaining a linguistic and conceptual ambiguity about the servile nature of work.

Consider the social role of salaried workers, but also the representation of those who hired out their capacity to work throughout the Middle Ages and early modern period. One encounters either a long succession of descriptions of salaried workers as voluntary serfs-always open to suspicion of dishonesty, and thus amorality, because they desire the money that they earn-or a systematic comparison of workers with serfs and slaves, because workers lose their physical liberty when they give over their time to their work. It is this notion of voluntary servitude, as it appeared in the discourses of the early thirteenth century, that underpins the perception of those who work for a salary, the mercenarii, as subjects solely characterized by their wish to obtain a salary (merces). ${ }^{6}$

4. Charles-Marie de La Roncière, Prix et salaires à Florence au XIV siècle, 1280-1380 (Rome: École française de Rome, 1982); Artigiani e salariati. Il mondo del lavoro nell'Italia dei secoli XII-XV (Pistoia: Centro italiano di studi di storia e d'arte, 1984); Claire Dolan, ed., Travail et travailleurs en Europe au Moyen Âge et au début des Temps modernes (Toronto: Pontifical Institute of Mediaeval Studies, 1991); Steven A. Epstein, Wage Labor and Guilds in Medieval Europe (Chapel Hill: University of North Carolina Press, 1995); Pietro Boglioni, Robert Delort, and Claude Gauvard, eds., Le petit peuple dans l'Occident médiéval. Terminologies, perceptions, réalités (Paris: Publications de la Sorbonne, 2002); Giuliano Pinto, Il lavoro, la povertà, l'assistenza. Ricerche sulla società medievale (Rome: Viella, 2008); François Bougard, Dominique Iogna-Prat, and Régine Le Jan, eds., Hiérarchie et stratification sociale dans l'Occident médiéval (400-1100) ('Turnhout: Brepols, 2008).

5. Jean-Yves Grenier, “'Faut-il rétablir l'esclavage en France ?' Droit naturel, économie politique et esclavage au XVIII ${ }^{\mathrm{e}}$ siècle," Revue d'histoire moderne et contemporaine 57 , no. 2 (2010): 7-49; Maria Luisa Pesante, Come servi. Figure del lavoro salariato dal diritto naturale all'economia politica, (Milan: Franco Angeli, 2013).

6. Giacomo Todeschini, Come Giuda. La gente comune e i giochi dell'economia all'inizio dell'epoca moderna (Bologna: Il Mulino, 2011). 
This association of the salaried worker with servitude can be related to both political discourse and the analyses of economic practices that began to develop in the late Middle Ages and were honed between the sixteenth and the eighteenth century. In fact, the development and intersection of certain notions-voluntary servitude, social abjectness, and the insignificance of salaried workers' labor compared to what was called the "common good"- took place in the language of moral theology and politics (in other words, in normative literature) from the thirteenth to the sixteenth century, and continued in the governmental theory that appeared in sixteenth- and seventeenth-century treatises of political philosophy. Since Adam Smith, classical economists have insisted on the freedom of the subjects participating in the market, and therefore on the virtual freedom of the market itself. However, it must not be forgotten that this freedom of participation was founded on preconceived ideas about the ambiguity of salaried work, a notion that economists inherited already weighed down by an age-old definition linking this type of work to servitude. Canon law, as Gérard Fransen has shown, had also considered the relation between salaried work and servitude, and clearly linked the manual labor of salaried workers, as a manifestation of the artes mechanicae practiced by the mercenarii, to servile work (opus servile). ${ }^{7}$

It is thus useful to begin an analysis of this archaeology with a reminder of the meaning of the Latin word mercenarius. In the late Middle Ages (and in fact since late antiquity), the term summarized an entire economic vocabulary, designating those who worked for a salary as a group distanced from active citizenship because their participation in building the common good $^{8}$ or collective wealth depended solely on the remuneration they received. ${ }^{9}$ For "economists" during the late Middle Ages and the beginning of the early modern period, as long as these individuals' contributions to the "common good" could be evaluated more or less precisely in terms of money or food, their work became a specific merchandise

7. Gérard Fransen, "La notion d'œuvre servile dans le droit canonique," in Le travail au Moyen Âge. Une approche interdisciplinaire, ed. Jacqueline Hamesse and Colette MurailleSamaran (Louvain-la-Neuve: Institut d'études médiévales, 1990), 177-84.

8. Élodie Lecuppre-Desjardin and Anne-Laure Van Bruaene, eds., De Bono Communi: The Discourse and Practice of the Common Good in the European City (13th-16th century) (Turnhout: Brepols, 2010).

9. Johannes Engels, "Merces auctoramentum servitutis. Die Wertschätzung bestimmter Arbeiten und Tätigkeiten durch antike heidnische Philosophen," in Arbeit im Mittelalter. Vorstellungen und Wirklichkeiten, ed. Verena Postel (Berlin: Akademie Verlag, 2006), 57-77; Patrice Beck, Philippe Bernardi, and Laurent Feller, eds., Rémunérer le travail au Moyen Âge. Pour une histoire sociale du salariat (Paris: Picard, 2014), part 1 "Historiographie," 19-148 (working versions: http://lamop.univ-paris1.fr/IMG/pdf/Salaire_salariat_1.pdf), part 4 "Les formes du paiement : évaluation des rémunérations," 301-485 (http:// lamop.univ-paris1.fr/IMG/pdf/Salaire_salariat_4.pdf), and the bibliography, 502-21; Giacomo Todeschini, "Wealth, Value of Work and Civic Identity in the Medieval Theological Discourse (XII-XIV c.)," in Petra Schulte and Peter Hesse, eds., Reichtum im späteren Mittelalter. Politische Theorie, ethische Handlungsnormen und soziale Akzeptanz (forthcoming). 
that they produced and hired out without really understanding its social value, and thus independently of the political meaning that institutions saw in the products of this work. For the same reason that a usurer's money was considered false capital in treatises on economics after the late eighteenth century-it was an unproductive sum until it left the usurer's hands and made its way into those of a merchant investor ${ }^{10}$ — the labor of salaried workers had no meaning as social capital when its value was represented by the salary that materialized a worker's wish to survive. On the contrary, this same labor became a productive value when, removed from the worker's control, it became a fragment of the collective wealth-in other words, of the common good.

What was the meaning, in premodern economic discourse, of the difference between the social insignificance of the labor physically produced by the hands of workers (masons, gravediggers, bakers, and barbers are the examples most often cited in the texts) and the exceptional value of the labor of those who sold an intellectual or political skill (such as architects, important merchants, senior civil servants, or military leaders)? It served to distinguish between abundance and rarity, and therefore the price of this "merchandise," but also to highlight the existence or the absence of an awareness of power, a skill, or an effective participation in the government of the political community. Social position, and thus an institutional role and an awareness of the honor that accompanied it, determined the value of labor. At the same time, within a context characterized by the equilibrium of the mystical and economic body of Christianity, salaried workers' economically and socially subordinate position was presented as the origin of their lack of insight and understanding of the meaning of their work. ${ }^{11}$

To consider these discourses in the late Middle Ages, one must read treatises on the organization of markets alongside texts of moral theology that set out a gradation of social value for trades. In other words, one must consider the penitential and anthropological distinction between trades that were licit or illicit, pure or impure, honorable or lowly alongside legislation organizing trades into a social hierarchy. Such a reading reveals that in distinct but quite compatible linguistic registers, the difference between the honor and dishonor of those who worked usefully ultimately depended on whether or not their activity was a manual one. Between the late Middle Ages and the early modern period, the ancient Ciceronian attitude identifying manual laborers as voluntary serfs and thus socially abject

10. Odd Langholm, Economics in the Medieval Schools: Wealth, Exchange, Value, Money and Usury according to the Paris Theological Tradition, 1200-1350 (Leiden: Brill, 1992); Giacomo Todeschini, I mercanti e il tempio. La società cristiana e il circolo virtuoso della ricchezza fra Medioevo ed Età Moderna (Bologna: Il Mulino, 2002); Todeschini, "Usury in Christian Middle Ages: A Reconsideration of the Historiographical Tradition (19492010)," in Religione e istituzioni religiose nell'economia europea, 1000-1800, ed. Francesco Ammannati (Florence: Firenze University Press, 2012), 119-30.

11. Joel Kaye, A History of Balance, 1250-1375: The Emergence of a New Model of Equilibrium and its Impact on Thought (Cambridge: Cambridge University Press, 2014). 
(merces auctoramentum servitutis, salary is the remuneration of a servitude) ${ }^{12}$ transformed into an articulate and complex discourse within which the dependence of salaried and especially urban workers ${ }^{13}$ was seen as a manifestation of their social inferiority, itself derived from the voluntary submission that made their vulnerability into a moral weakness. Evidence of this semantic and political transition can be found in the notarial formalization of contracts of voluntary servitude that took place between the fourteenth and the sixteenth century, ${ }^{14}$ as well as in urban legislation formally excluding salaried workers from participation in government-and thus from full citizenship_as dirty-handed laborers, servile subjects entirely exposed to the will and moral choices of their masters. It is also present in the arguments of canonists and civilists about the impossibility of trusting the common people, and thus the poor majority. Here it is useful to recall an essential text for Western legal history, the Glossa to Gratian's Decretum. According to the Glossa, a judge faced with an unknown witness could ask outright "whether he is of servile condition or a free man" in order to identify him and thus evaluate his reliability. This might involve subsequently verifying the reply by questioning the known and credible persons (or persons considered as such by the judge) with whom the unknown witness had had dealings in order to confirm his reputation (and perhaps origin). ${ }^{15}$

At the same time, as François Menant recently highlighted, lists of trades drawn up in the Middle Ages and early modern period clearly emphasize the "typically popular" nature of certain occupations and the ambiguous identification of those who practiced them with the "common people," that subjugated and indigent group forever dangling between servitude and freedom, between a modest dignity and the infamy of illegality.

Certain trades were considered typically popular. ... The list of trades that preachers considered ignoble and reserved to the lower classes (associated with a suggestion of poverty

12. See for example Cicero, De officiis 1.150. On this question, see Engels, "Merces auctoramentum servitutis." For a more general perspective, see: Pascale Lambrechts and JeanPierre Sosson, eds., Les métiers au Moyen Âge. Aspects économiques et sociaux (Louvain-laNeuve: Université catholique de Louvain, 1994); Jacques Le Goff, "Licit and Illicit Trades in the Medieval West" [1963], in Le Goff, Time, Work, and Culture in the Middle Ages (Chicago: University of Chicago Press, 1980), 58-70.

13. Mathieu Arnoux, Le temps des laboureurs. Travail, ordre social et croissance en Europe, $X I^{e}-X I V^{e}$ siècle (Paris: Albin Michel, 2012); Étienne Anheim, "The History and Historiography of Guild Hierarchies in the Middle Ages," Annales HSS (English Edition) 68, no. 4 (2013): 1027-38.

14. Beck, Bernardi, and Feller, Rémunérer le travail, especially part 2, "Salarium, stipendium, dieta. Approche terminologique de la rémunération du travail," 149-241 (working versions: http://lamop.univ-paris1.fr/IMG/pdf/Salaire_salariat_2.pdf), and part 3, "Les modes de rémunération du travail : formes de l'embauche et rémunération du paiement," 243-300 (http://lamop.univ-paris1.fr/IMG/pdf/Salaire_salariat_3.pdf), in particular Philippe Bernardi, "Quelques éléments sur le choix de la forme de l'embauche dans la Provence des XIV e et XV siècles," 38-52.

15. Giacomo Todeschini, Visibilmente crudeli. Malviventi, persone sospette e gente qualunque dal Medioevo all'Età Moderna (Bologna: Il Mulino, 2007). Available in French as Au pays des sans-nom. Gens de mauvaise vie, personnes suspectes ou ordinaires du Moyen Âge à l'époque moderne, trans. Nathalie Gailius (Lagrasse: Verdier, 2015). 
and a position among the common people) [includes]: operarius (pieceworker), prostitute, usurer, sewer worker, itinerant wine seller, watchman, collier, shepherd, goose keeper, washerwoman (faciens lexiviam), thief, wet nurse, weaver, miller, peasant, cobbler ... We should note the presence of trades practiced by women: whether alone (notably as widows responsible for a family) or as partners of poor workers, women were particularly vulnerable to poverty and the obligation to take up humble and arduous occupations. A list of poor workers from 1344, this time a real one, echoes the professional classifications drawn up by the preachers, but nuances their rather schematic vision by incorporating social mobility, in this case of the downward kind. Upon his death, the Lucchese merchant Giacomo Galganetti bequeathed alms of silver and clothing to 655 of the city's poor people and families. The list of recipients, all of whom were workers (or their widows), specifies the trades that they practiced, though not whether they were independent artisans or laborers. One section relates to 158 young girls, mostly from the contado, awaiting marriage with boys practicing these same professions. Galganetti helped them amass the indispensable dowry - a kind of alms often practiced at this time since the increasingly costly custom had become an insurmountable obstacle to many marriages. The lamentable sequence of indigents includes 12 weavers, 14 tailors, 13 cobblers, as well as a schoolmaster, two notaries, and three individuals bearing the title of ser, which indicated a certain notability. In short, every trade and circumstance of the popolo is represented among these middleorworking-class families that had slipped into poverty. These poor individuals undeniably also counted as "the people," but a version particularly marked by the social decline of the "lower middle," who, before they fell on hard times, had occupied the upper stratum of the groups regarded as "popular."16

Matthieu Scherman's recent book on the social status of workers and the organization of work in Treviso during the fifteenth and sixteenth centuries has shown the extent to which salaried work could be socially "depreciated" in an economically developed European city. ${ }^{17}$ The social history of salaries at the beginning of the early modern period can thus shed light on the history of the social role attributed to workers, or on certain aspects of the history of economic thought relating to salaried work and what it came to mean in the abstract framework of definitions of "economic development."

Samuel von Pufendorf's discourse on the natural inequality of men (and even on the relationship between natural law and servitude), like that of Hugo Grotius on varieties of servitude, thus appears to have a complex origin. ${ }^{18}$ On the one hand,

16. François Menant, "Approches du peuple médiéval," text of the paper presented at the seminar "Les sociétés européennes au Moyen Âge: modèles d'interprétation, pratiques, langages, 2011-2012. Comment étudier les milieux populaires urbains de la fin du Moyen Âge ?" by Menant and Diane Chamboduc de Saint-Pulgent, p. 27: http://www.histoire.ens.fr/IMG/file/Menant/Introductionséminaire2011-2012, ApprochesdupeupleauMoyenÂge.pdf.

17. Matthieu Scherman, Familles et travail à Trévise à la fin du Moyen Âge, vers 1434-vers 1509 (Rome: École française de Rome, 2013).

18. Samuel von Pufendorf, Of the Law of Nature and Nations [1672], trans. Basil Kennett (London: J. Walthoe et al., 1729; facsimilie ed. Clark, NJ: Lawbook Exchange, 2005), bk. 3, chap. 2.8, pp. 230-32; Hugo Grotius, Of the Rights of War and Peace [1625] (London: D. Brown, T. Ward, W. Meares, 1715), 2:134. For an analysis of these texts see respectively Grenier, "Faut-il rétablir l'esclavage," and Pesante, Come servi. 
these discourses draw on the definition of servitude and slavery as the result of a corruption of the law of nature deriving from original sin, a line of thought developed by Aristotelian-Thomist and neo-Augustinian Scholasticism, but also assimilated and rationalized by civilists in terms of the cognitive incapacity of the poor. On the other hand, they were inspired by the development of an oligarchic form of government, apparent in Italian cities during the fourteenth and fifteenth centuries, based on the political and economic devalorization of the labor of salaried workers. This devalorization connected the notion of the mercenarii and artifices as economically and politically inferior because they worked with their hands to that of their civic incompetence and intellectual crudeness as viles personae, servile subjects incapable of understanding the meaning of their work within the larger framework of the "common good." The awareness that a difference existed between this type of work and the economic activism of entrepreneurs, merchants, and bankers - in other words, of those who governed-was thus summarized and transmitted by fifteenth-century manuals for merchants. These texts starkly opposed the physical energy and intellectual subtlety of the important merchant to the mental inertia and brute force of manual laborers, and explicitly distinguished major enterprises connecting industry and finance from the minor, everyday affairs of small shopkeepers. ${ }^{19}$

Here lies, perhaps, the root-not yet systematized in terms of theoretical discourse or an economic program, still to be established as an organic component of the economic thought of economists-of what Piketty describes as "meritocratic beliefs ... invoked to justify very large wage inequalities, which are said to be more justified than inequalities due to inheritance." From this perspective, we might move beyond the non-meritocratic culture of the privileged since the early nineteenth century, and identify a much older origin for the fact that "modern meritocratic society ... is much harder on the losers, because it seeks to justify domination on the grounds of justice, virtue, and merit, to say nothing of the insufficient productivity of those at the bottom."20

In a presentation given in 2013, Piketty noted that "this can be the worst of all worlds for those who are neither super-managers nor super-inheritors: they are poor, and they are depicted as ... undeserving." 21 The answer to how such a rhetoric

19. A well-known example is Benedetto Cotrugli, Il libro dell'arte di mercatura [1458], ed. Ugo Tucci (Venice: Arsenale, 1990), 139 and 145. See Giacomo Todeschini, "Theological Roots of the Medieval/Modern Merchants' Self-Representation," in The SelfPerception of Early Modern Capitalists, ed. Margaret C. Jacob and Catherine Secretan (New York: Palgrave Macmillan, 2008), 17-46; Todeschini, Franciscan Wealth: From Voluntary Poverty to Market Society, trans. Donatella Melucci (New York: St. Bonaventure University, 2009).

20. Piketty, Capital, 416.

21. Piketty, conference on "Inequality \& Capitalism in the Long-Run," http://piketty. pse.ens.fr/en/lectures. 
justifying inequalities developed can undoubtably be sought in the history of the categories and vocabulary of European economics and law.

This "archaeology" leads to a new observation regarding the relation between the false meritocracy of rentiers and the prodigious and magical aspect of rent from capital. Describing the mechanism of rents and inheritance, Piketty writes: "To be sure, there is something astonishing about the notion that capital yields rent, or income that the owner of capital obtains without working. There is something in this notion that is an affront to common sense and that has in fact perturbed any number of civilizations, which have responded in various ways, not always benign, ranging from the prohibition of usury to Soviet-style communism." 22 It must be emphasized, however, that the prohibition of usury never called into question the right of the wealthiest to enrich themselves by investing their capital for profit-either during the Middle Ages or in the early modern period. On both the legal and the theological level, a subtle but perfectly intelligible distinction between usury and the productivity of capital was established very early on. As early as the thirteenth century, it was emphasized that the social value, and therefore the economic meaning, of the productivity of money pertained to the social and political role of the capitalist. ${ }^{23}$ In other words, the holder of capital was recognized by the markets as a professional investor, essential because of the risks taken by investors and their capital for the growth of what was then called the common good, and would come to be called collective prosperity, even universal happiness. ${ }^{24}$ European institutional wisdom thus began from an early date to assert the existence of a clear distinction between the illegality of the parasitic rent of the usurer and the legality, even the prestige and morality, of the rent that served as profit for the capitalist merchant and banker.

Giacomo Todeschini Università di Trieste

22. Piketty, Capital, 423-24.

23. Todeschini, I mercanti; Giovanni Ceccarelli, Il gioco e il peccato. Economia e rischio nel tardo Medioevo (Bologna: Il Mulino, 2003); Ceccarelli, "Risky Business: Theological and Canonical Thought on Insurance from the Thirteenth to the Seventeenth Century," Journal of Medieval and Early Modern Studies 31, no. 3 (2001): 607-58; Guido Alfani and Roberta Frigeni, "Inequality (Un)Perceived: The Emergence of a Discourse on Economic Inequality from the Middle Ages to the Age of Revolutions," Dondena Working Paper 58 (2013): http://www.dondena.unibocconi.it/wps/wcm/connect/cdr/centro_ dondena/home/working+papers/working+paper+58.

24. Jean-Yves Grenier, L'économie d'Ancien Régime. Un monde de l'échange et de l'incertitude (Paris: Albin Michel, 1996); Emma Rothschild, Economic Sentiments: Adam Smith, Condorcet, and the Enlightenment (Cambridge: Harvard University Press, 2001). 